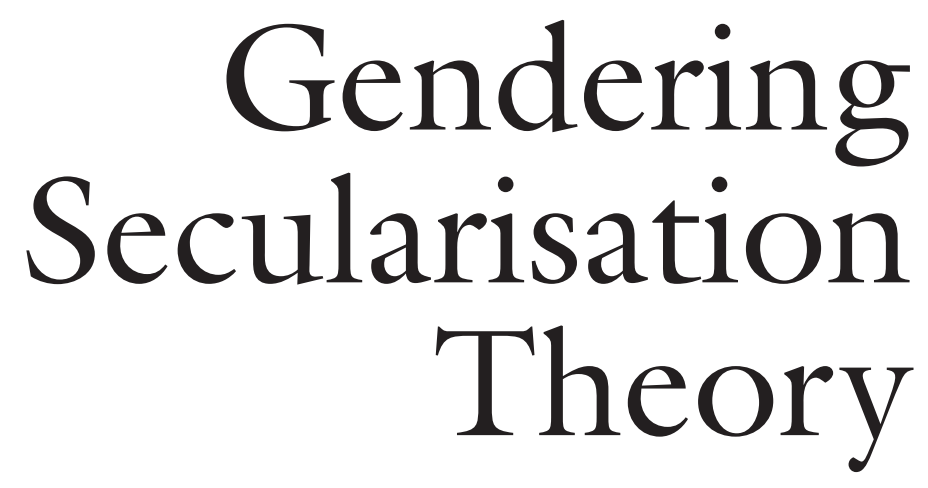

Af Linda Woodhead

Are major theories of secularisation gender blind? And have men's experience of modernisation been made central to explanations of veligious decline? Greater attention to women's distinctive experiences can belp answer these questions and extend the explanatory power of secularisation theory.

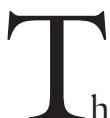

he gender-blind approach which has long characterised the sociology of religion not only ignores gendered difference, but assumes that the masculine point of view is normative. Since the 1970s this perspective has gradually been challenged, not least by empirical studies whose findings make it much harder to ignore the salience of gender differences in the realms of religion and spirituality (Woodhead 2001). As yet, however, the classical theories of secularisation which still dominate the discipline have not been interrogated by a gendered approach. This paper offers some preliminary suggestions about possible implications for such theories of a broadening of their perspective to take account of the situation of women as well as men in the modern world. The aim is to show that the gendering of secularisation theory has the potential to enhance its explanatory power.

What follows is intended to be suggestive and provocative. My aim is to open up 
new avenues of exploration, rather than to present a systematic new (gendered) theory of secularisation. I will focus on two of the most important classical narratives of secularisation - those of Weber and Marx - and on one of the most influential re-formulations of these narratives - that presented by Peter Berger, Brigitte Berger and Hansfried Kellner in The Homeless Mind (1974). I will make suggestions about what happens once we begin to 'gender' these accounts of secularisation, and in doing so will make reference to a selection of both qualitative and quantitative data which has a bearing on the enterprise. This data will be drawn from English-language sources, and will chiefly relate to the British Isles. I will occasionally make reference to data relating to other parts of Europe and north America, chiefly for the purpose of comparison. Secularisation is a multi-dimensional concept, which may refer to the decline of engagement with the sacred in (a) society (b) the sphere of religion itself (c) the life of the individual (Dobbelaere 2002). Though the narratives of secularisation with which I begin cast their nets widely, in the discussion that follows I will concentrate chiefly on (b), focusing in particular on changes in Christian life and thought, including the decline of church attendance and membership.

\section{NARRATIVES OF SECULARISATION}

Amongst many other things, Karl Marx and Max Weber bequeathed to the sociology of religion two powerful narratives of secularisation which have exerted an influence ever since. The first tells how modern individuals have come to dwell in an 'iron cage'; the second how they have come to dwell in a 'crumbling cage'. ${ }^{1}$

In The Protestant Ethic and the Spirit of Capitalism (orig. 1904-5) and elsewhere, Weber looks back on a pre-modern world which was imbued with sacred and mysterious meaning. Meaning lay deep below - or high above - the immediate surface and utility-value of things, and was articulated by way of the powerful images, stories, worldviews and rituals of religion. Modernisation, however, has involved a progressive demystification and disenchantment of the world, as transcendent meaning has been pushed aside to make way for the more pressing and immediate needs, demands and protocols of industrial capitalism. "The tremendous cosmos of the modern economic order", writes Weber (1996),

is now bound to the technical and economic conditions of machine production which today determine the lives of all the individuals who are born into this mechanism... with irresistible force (p. 181).

The result is a world which is governed and shaped not by sacred meaning but by the harsh and impersonal standards of a 'rationalised' and 'bureaucratised' order whose only aim is greater productive efficiency. Human beings become cogs within machines that neither appreciate nor accommodate their feelings, hopes, desires and dignity. Their 'soft' selves are crushed and constrained to fit into the hard and impersonal structures of the factory, the office, and the organisation. From being a mere means to serve the greater and more fulfilling ends of human life, the production and consumption of external goods becomes the motive force driving both individual and social life. "In Baxter's view" comments Weber (1996),

care for external goods should only lie on the shoulders of the 'saint like a light cloak, which can be thrown aside at any moment'. But fate decreed that the cloak should become an iron cage [...] Of the last stage of this development, it might well be truly said: 'specialists without spirit, sensualists without heart' (p. 181). 
Religion has a threatened and precarious place in the rationalised world of the iron cage, for at least two reasons. First, that which supplies the world with mystery and meaning can have no place in a world governed by rational-scientific modes of thought. There is no need to bless crops when fertiliser produces more consistent results; no point in casting out demons when medicine offers more reliable cure; no purpose in spending hours in prayer when the time could be spent making money. Indeed, religion comes to be seen as a positive hindrance to progress: superstition which must be routed by reason, an assemblage of priest-ridden institutions which must be swept away and replaced by more efficient forms of social, political and economic organisation. Second, as social functions are parcelled out into different spheres of specialised activity for the sake of greater efficiency, so a new public world comes into being in which religion loses its place. The spheres of law, education, welfare, politics and so on become differentiated from one another and from the sacred. Increasingly they run along rational-bureaucratic lines. No longer responsible for shaping the values and aspirations of society as a whole, religion must be content with trying to retain a hold over the private lives of individuals.

Marx's story is different from Weber's or at least the emphasis falls differently: Not on an iron cage but on a crumbling cage. For Marx what differentiates industrial capitalism from what preceded it is amongst other things - the sheer pace of change. The authority of 'tradition', of the way that things were always done, gives way to the authority of capital. Revolution succeeds revolution, as more efficient modes of production give way to one another at an accelerating pace. As Marx and Engels put it in one of the most frequently quoted passages of The Communist Manifesto (orig. 1848):
Constant revolutionising of production, uninterrupted disturbance of all social conditions, everlasting uncertainty and agitation... All fixed, fast-frozen relations, with their train of ancient and venerable prejudices and options, are swept away, all new-formed ones become antiquated before they can ossify. All that is solid melts into air, all that is holy is profaned $(1977,224)$.

Unlike Weber, Marx has little nostalgia for religion and its "venerable prejudices"; in his view its main effect is to inure the oppressed to their suffering. Like Weber, however, he sees the costs for human life of the new modes of existence called into being by the industrial age. Rather than life being shaped around human meaning which can be reverenced and sustained, it is alienated from itself by the demands placed on it by the constantly changing modes of production which characterise the capitalist system.

At first sight the images and narratives of iron cage and crumbling cage appear incompatible: how can that which is rigid, fixed and constricting also be melting, dissolving and shape-shifting? One of the achievements of Berger et al's The Homeless Mind (1974) was to show that far from being mutually exclusive, the two may be woven together to form a single narrative of even greater explanatory power than each possesses on its own. For not only is it the case that the life of modern individuals is constrained by iron cages which are not responsive to the quest for meaning and significance, it is also the case that these rigid structures are constantly being superseded and rendered redundant by other equally rigid and meaningless cages. One's life may be shaped by one set of discourses and practices - say that of heavy manufacturing industry - but within the same lifetime one may see that way of life rendered obsolete by a shift towards service industry. For the flows of capital that characterise the modern globalised economy are no re- 
specters of personally- and socially-meaningful forms of life.

The effect, according to Berger and his co-authors, is to undermine the overarching 'sacred canopies' which once made sense of social life by relating it to wider economies of meaning - like the world of gods and spirits. For example, fixed forms of agricultural practice were once rendered meaningful by being related to myths and rituals which explained their origins and $\mathrm{cy}-$ cles of fertility, but the 'agro-businesses' of today can admit no meaning beyond the generation of profit for their owners and shareholders. The land loses its sacredness, and cultivation becomes purely mechanistic. Similarly, where patterns of gender and class relations could once be explained and sanctified by being mirrored by divine hierarchies and sacred stories, now human relations are cut free from any wider contexts of meaningfulness. We all become de facto social scientists, capable of seeing through what was once held sacred to the function it performs and the interests it serves. Under these conditions the forms of religion which suffer the most serious loss of plausibility are those which were once most effective in serving as sacred canopies over (pre-modern) forms of life. As the latter are undermined, so too are the religions which once made them seem sacred.

Thus Berger's account of secularisation states that pluralism - not only of contemporaneous but of successive forms of life undermines plausibility and leads directly to secularisation. ${ }^{2}$ This does not mean the end of all sacred belief and practice. Unable to find adequate meaning either in the public world or in the forms of religion which once partnered it, the modern mind finds itself 'homeless', and is thrown back on its own resources. The only place in which meaning and value can now be located is in the depths of one's own subjective life, and the forms of the sacred which do best will be those which are able to resource the quest for inner significance. ${ }^{3}$
Before moving on from this brief survey of secularisation narratives, it is worth drawing attention to a basic assumption with which they tend to operate, namely that society is composed chiefly of (a) primary institutions - like the workplace, the legal profession and associated institutions, the political establishment, higher education and so on - which are large-scale (operative throughout society), public, and assumed to be central to the healthy functioning of (modern) society and (b) the individual self who is thrown into and up against these institutions without having any choice in the matter. The significance of this model of society - and its gendered assumptions - will become clearer in what follows.

\section{GENDER AND SECULARISATION IN INDUSTRIAL SOCIETY}

Because they take male experience to be normative, the narratives of secularisation under discussion assume that modern men and women are affected in exactly the same way by the harsh captivity of the iron cage and/or by the destabilising effects of the crumbling cage. Once we take account of gender difference, however, this assumption comes into question. We can examine some implications of the gendering of secularisation theory first in relation to industrial society (particularly the 19th century, at least where Britain is concerned), then in relation to late industrial society (particularly from the 1960s).

Although there is considerable debate amongst historians about the nature of women's work in the pre-modern and early modern periods, there is greater agreement about the fact that industrial capitalism is characterised by strong differentiation of male and female labour. 4 The former now takes place within the public world of office, factory or field, whilst the latter - increasingly - takes place within the 'private' world of the home. The former is economi- 
cally rewarded, whilst the latter is not. Of course this simple picture needs to be qualified in a number of ways, not least by taking into account class differences. Since few working class households could afford for their womenfolk not to work for pay, working class women were more likely to undertake paid employment than middle class women. This class variation does not, however, qualify the general picture of differentiation between the male 'public' work and female 'domestic' work as much as might be supposed, because (a) even those women who worked for pay still had to take prime responsibility for domestic labour and (b) a great deal of women's paid work was piece-work which was carried out within the home. Moreover, even the women who were engaged in paid labour outside the home tended to be engaged in 'domestic' forms of labour - most importantly domestic service, teaching and nursing (Abrams 2002).

In other words, it was men who were likely to find their lives and labour shaped by the iron cage and the crumbling cage rather than women - for it was men who entered the public world of paid work rather than women. Likewise, it was men who were likely to be shaped as - and to think of themselves as - lonely and isolated individuals struggling against the impersonal, bureaucratic, but ultimately impermanent structures of primary institutions. By contrast, the vast majority of women would have found themselves located primarily or exclusively within a domestic context within the home, within the family. As such, they would be far less likely to experience society as a set of primary institutions which throw the individual back on his or her own personal resources. They would be shaped, instead, by domestic experience and the roles and duties of daughter, wife, mother, aunt, grandmother and so on. Women's mode of selfhood, in other words, was likely to be domestic-relational, whilst men's was much more likely to be atomistic-individual. (Since accounts of the development of modern selfhood tend to be gender-blind, they naturally tend to focus on the rise of the latter mode of selfhood - see, for example, Abercrombie, Hill, Turner (1986)).

Relating this back to religion and theories of secularisation, for men 'public' religion is likely to be undermined by the rational disenchantment of the world and by the profanation of 'timeless' truth by the onward march of change. For women, however, such depredations are likely to have far less impact on traditional religious commitment. For one thing, women are not absorbed into a world dominated by rational-scientific modes of thought and action, and so are less likely to become disenchanted with the supposedly irrational or superstitious nature of religious belief. For another, since they are not as subject to the effects of rapid change, they are less likely to find that the sacred canopy which 'enchants' their own lives as it did that of their mothers and grandmothers is undermined by the forward march of progress. Women are also less likely to be thrown back on the resources of the solitary self, for the intermediate organisations of family and neighbourhood - including many churches ${ }^{5}$ still shape the self through regular and meaningful contact with other people (not merely with 'cogs' in machines).

One thing that gendered secularisation theory might therefore lead us to expect in quantitative terms - is that in industrial societies there will be fewer men than women active within the churches (and probably in other forms of religious activity as well). More concretely still, we might expect to find that as societies industrialise, so men's church attendance and membership will decline at a faster rate than women's. Although data on church attendance and membership in Britain differentiated by gender is relatively rare, ${ }^{6}$ it does seem to lend some support to this expectation. The fullest information is supplied by Clive 
Field (1993), who surveys a range of different sources of information, most importantly Nonconformist (particularly Baptist and Congregationalist) church membership records. Drawing on the latter, he finds that between 1750 and 1800 there was a three-fifths female majority in Baptist and Congregational membership, whereas after this period it rose to a two-thirds majority - perhaps as industrialisation took hold? (see Table 1).

\section{Period}

$\%$ of women members

1751-75

1776-1800

58.6

1801-25

54.8

$1826-50$

60.7

$1851-75$

65.2

1876-1900

67.2

1901-25

67.6

1926-50

68.6

66.8

Table 1: Women as a percentage of all members in Baptist and Congregational Nonconformity, 16511950: Combined figures by quarter century.

Source: Field $(1993,66)$

Of course we have a great deal more undifferentiated data which allows us to gauge overall patterns of church growth in industrial Britain. Here the best survey of various sources is that presented by Currie, Gilbert, and Horsley (1977). The picture that emerges is of little or no growth in the 1700s, except amongst nonconformists, of growth between 1800 and 1840, and lower growth between 1840 and 1910, and decrease after 1910 and 1970 (pp. 21-38). Far from leading directly to decline, industrialisation therefore seems to have led to growth, for a short time at least. Could this be because even though some men were defecting, women remained far more loyal to the churches and active within them?
And can women's continuing allegiance explain why decline was not more precipitious between 1910 and 1970? We cannot say for sure, given the lack of evidence. We do, however, know that by the start of the twentieth century women were preponderant in British Christianity and have remained so ever since. For example, Robin Gill (2003) finds that in London and York at the beginning of the $20^{\text {th }}$ century church attendance was predominantly female; and in the USA Robert and Helen Lynd (1929) found women accounting for about $60 \%$ of churchgoers in 'Middletown' in 1924-1925 (p. 355). For an overview of the voluminous post-war evidence on women's greater involvement, see Argyle and Beit-Hallahmi (1975, 71-9).

The explanatory and predictive gains of the gendering of secularisation theory are somewhat easier to assess in relation to qualitative material, where data is more abundant. What gendered theory would lead us to expect is not only a drawing apart of the realms of public life and church life, but a drawing closer of the realms of family life and church life - such that the former is Christianised and the latter is feminised and domesticised. Historical studies of church and society in both Europe and America seem to bear out this prediction across a range of different areas.

For one thing, there is considerable evidence that both Protestant and Roman Catholic churches placed increasing emphasis upon the value of the family and domestic life in industrialising society (Roper 1989, Davidoff and Hall 1987, Woodhead 2004). The shift was particularly striking within the Catholic Church which, in preindustrial society, had attributed only a qualified and secondary importance to the family, with the celibate and monastic life being considered a higher calling. By the 19th century, however, the 'holy family' in the heavens had become a model for the (nuclear) family on earth (Heimann 1995, Kennelley 1989). 
In addition, women's role and status in both heaven and earth receives new attention and validation from church authorities, with the Roman Catholic Church - for example - declaring the dogma of the Immaculate Conception of Mary in 1854 and the Assumption of the Blessed Virgin Mary in 1950. At the same time, the role of mortal woman is attributed new dignity, insofar as woman exemplifies the virtues of chastity, humility, maternal care, and obedience (the virtues of the convent are popularised and domesticised). At the same time, churches become internally 'feminised', with serious consequences for their power and prestige in society, and for that of their male clergy (Douglas 1978, Hartman 2001). As the masculinity of church and clergy is called into question, so there arise reactions including repeated calls for more 'muscular' forms of Christianity which can win back the men and the boys (Putney 2001).

Dominant images of God also undergo corresponding changes. Emphasis on the harsh, commanding, angry and even arbitrary God worshipped and honoured as a 'King' and 'Judge' gives way to emphasis on a gentler, kinder, more considerate and loving God who displays universal benevolence towards his creatures (Nichols 1989). Whilst remaining unquestionably male, this God takes on more fatherly, loving and caring characteristics. Jesus is also pictured as an idealised lover or husband who is caring and considerate, kind and good, commanding and strong (Clark-King 2005, Woodhead 2005, 128-145).

Thus a gendered perspective allows us to see that church decline in industrial society is likely to be due to male rather than female defection (with continuing female adherence slowing down the process), and that a 'domesticisation' and 'feminisation' of religion also takes place as religion is internally transformed by male defection and de-identification.

\section{GENDER AND SECULARISATION}

IN LATE INDUSTRIAL SOCIETY

(FROM THE 1960s)

If women's lives were far less directly affected than men's by iron cage and crumbling cage in industrial times, this situation changed significantly in the watershed period after the Second World War when industrial society give way to late industrial society across much of the west - and in some other parts of the world. One of the many changes which took place was a farreaching shift in women's status and roles in society, which involved (amongst other things) their entry into the paid workforce in unprecedented numbers. The latter development had begun earlier in the $20^{\text {th }}$ century, was given impetus by labour shortages during the two World Wars, and continued at a rapid pace after the 1960s. As Ferber (1998) puts it:

Women's labor force participation has been increasing in most of the world. In the United States, for instance, it began rising late in the nineteenth century. At first it increased slowly from 18.2 per cent in 1890 to 27.9 percent in 1940 , then far more rapidly to 58.9 per cent in 1995 (p. xii).

This can be compared with the very similar situation in the EU in which $60 \%$ of women were active in the workforce in 2001 and $78 \%$ of men (Thewlis, Miller, Neathey, 2004).

Women's entrance into the public sphere, even if not on equal terms with men, would nevertheless bring them into

Den Hellige Familie. Rembrandt 1630'erne. Oliemaleri $183 \times 123 \mathrm{~cm}$, Alte Pinakothek, München 
direct contact with the stresses and strains of iron cage and crumbling cage as never before. Taking this into account, a gendered theory of secularisation can predict an increased rate of defection from the churches from the 1960s onwards. If women as well as men are now growing disillusioned with Christianity we can also expect to find that rates of church decline will increase significantly. The most reliable data from the UK is certainly compatible with this scenario (see Table 2). If we step even further back in time to 1851 when Mann carried out his famous census of $R e^{-}$ ligious Worship in England and Wales (1854), the percentage of the population attending church on census Sunday was around 39 per cent, although this may fall to about 24 per cent if those who attended two or more times are only counted once (Gill, 1993). Overall the picture is one of gradual decline in both membership and attendance after 1910, with a short 'blip' of growth in the 1950s, followed by accelerated decline from the 1970s to the present decline which currently shows no sign of slowing down. (Whilst the nature of the situation in the USA is highly debated, there is growing evidence that there has also been significant secularisation there since the 1970s. For a review of the evidence see Heelas and Woodhead (2004), 55-68.)

\section{Congregational Membership (\% of population)}

$\begin{array}{llll}1900 & 1930 \quad 1960 \quad 2000\end{array}$

$\begin{array}{llll}33 & 29 & 24 & 12\end{array}$

Typical Sunday attendance (\% of population)

$\begin{array}{ccccc}1903 & 1951 & 1979 & 1989 & 2000 \\ 19 & 15 & 12 & 10 & 8\end{array}$

Table 2: Church decline in Britain (source: Heelas and Woodhead 2004, 139).
Thus whilst gender-blind theories of secularisation struggle to account for the gathering pace of secularisation after the 1960s, a gendered approach has far less difficulty. If secularisation is due simply to the unfolding of the stories of secularisation outlined at the start of this essay, then it is hard to see why it should suddenly speed up in the last quarter of the 20th century. But once we acknowledge that the secularising pressures which had long affected men are suddenly brought to bear on increasing numbers of women as well, the data becomes much easier to interpret. So far as we can tell, the ratio of women to men has remained fairly steady within the churches in the $20^{\text {th }}$ century, but this still means than greater numbers of women than men have defected during this period, hence speeding up the overall rate of decline. (A gendered approach can also help explain the 'blip' of church revival in the 1950s. The immediate post-war years witnessed a brief revival of the domestic ideal, and of the idea of 'separate spheres' for men and women. (See Tyler 1988). For reasons explained above, this would naturally go hand in hand with a return to church on the part of women and families.)

It is, however, too simple to see women's labour patterns as simply being assimilated to men's from the 1960s onwards. Though they may be diminishing, there are still very significant differences between the patterns of male and female labour, attention to which can yield still more information about the nature of recent secularisation - and sacralisation (i.e. the decline of traditional 'religion' and the growth of new forms of 'spirituality').

Three main differences emerge as particularly significant. First, women are still disproportionately engaged in part-time paid labour. In 2001 they made up more than four-fifths $(81.4 \%)$ of all part-timer workers in the EU (Thewlis, Miller and Neathey, 2004, 23). Second, women still carry out the bulk of unpaid caring work, 
Table 3: Female share of employment by occupation, 2001

\section{Occupations}

Legislators, senior officials and managers

Professionals

Technicians and associate professionals

Clerks

Service workers and shop/market sales workers

Skilled agricultural and fishery workers and elementary occupations

Craft and related trade workers

Plant and machine operators and assemblers All

Source: Thewlis, Miller and Neathey 2004, p. 17

$\begin{array}{ccc}\text { Denmark \% } & \text { Ireland \% } & U K \% \\ 23.0 & 27.9 & 30.0 \\ 40.0 & 51.7 & 39.6 \\ 56.1 & 42.0 & 46.6 \\ 73.1 & 73.9 & 78.9 \\ 78.4 & 64.1 & 76.1 \\ 41.8 & 33.3 & 45.7 \\ 5.4 & 5.8 & 8.3 \\ 25.3 & 22.7 & 17.3 \\ 46.4 & 40.9 & 44.9\end{array}$

1970 , but had declined to 55 by 1990" (p. xv) (see also Wharton 2005).

Overall then, the picture of women's labour (paid and unpaid) is more variegated than that of men's labour. Women find themselves in a range of different work positions, of which three seem particularly important: First, women employed full-time in primary institutions, who may be expected largely to share the same experience of labour and the workplace as men. Second, women who are employed full- or parttime in primary institutions, but who also have prime responsibility for the care of children and other dependants. Women in this category will often find their lives divided between primary institutions (and paid labour) and secondary institutions, particularly the family (and unpaid labour). In the popular jargon they find themselves 'juggling' two very different sets of demands and two incompatible standards of behaviour and evaluation (the rationalistic, utilitarian-individualist and the relational, domestic). Third, women whose lives are lived primarily in the context of family and 
domestic care, and who are not employed in primary institutions (or only in 'domestic' forms of care, such as part-time care of children).

What are the implications of this variegated picture of women's work for religious belief and commitment? It is possible to hypothesise that each of the three different subject- and work-positions will have an elective affinity with a different religious or spiritual stance. Thus in the first category women who share a typically male experience of the workplace - and thus of iron cage and crumbling cage - are likely to find this equally corrosive of religious commitment. In addition, women's alienation from Christianity in particular may be the greater if the latter is experienced as reinforcing the domestic values which these women no longer endorse - since these moral imperatives tend to bear down more heavily on women than on men (Brown 2001).

The situation for those women in the second category who 'juggle' work and home may be rather different. Since they are caught between two different sets of norms, values and expectations, they may chose to privilege one over the other. If they privilege the role of autonomous agent, they may be alienated from Christianity. If they privilege the role of wife, mother, carer and relational agent, they may be much more likely to continue to have a church commitment, and to find within the church validation and legitimation for their domestic roles. Alternatively, however, the 'jugglers' may find themselves experiencing some sort of cognitive dissonance, and seek some way of integrating and 'centring' their fragmented experience. So far as the sacred is concerned, they may find help in this regard in the many forms of 'holistic' spirituality which have proliferated since the sixties (particularly in the last decade or two). As we discovered in recent research (Heelas and Woodhead 2004), holistic spirituality caters predomi- nantly for women, as well as being predominantly 'run' by women (in Kendal in the UK where we carried out our research, 80\% of those engaged in holistic spirituality both as practitioners and clients were female). What is more, such spirituality is primarily concerned with catering for the stresses and strains of female life, including dealing with issues of overwork, stress, and lack of self-confidence. On the one hand, women's work of care and relationality is affirmed. On the other, great stress is placed on the imperative to care for the 'wellbeing' of the self, and to realise that only if one cares for oneself can one care effectively for others. Thus the sacred is engaged to resource and refresh the depths of one's subjective life, as well as to endorse caring and responsible relation with others.

By contrast, those women whose primary and overriding roles remain those of wife and mother within the domestic setting are the most likely to find that themselves sheltered from the corrosive effects of modernisation - of iron cage and crumbling cage. For them, the churches' legitimation and support of women's caring roles and of the family in general may provide a haven in a late capitalist society which tends to value autonomous rather than relational-domestic selfhood. Thus a number of empirical studies of conservative Christian and Jewish groups and organisations in the USA find that they are highly successful in attracting - and in some cases converting - women with families. For example, Griffith (1997) shows how the conservative Christian 'Women's Aglow' movement validates women's work of care by combining traditional Christian teaching with some therapeutic emphases to help them 'cope'. She cites a prayer from Aglow in the Kitchen, a cookbook for Christian wives, which shows very clearly how Christianity sanctifies domesticity: "Jesus, thank You for showing me that housework is sacred. Help me to realize while I am cooking and cleaning that I am doing them for You because You are living 
here and my husband is Your representative" (p. 182). Similarly Davidman (1991) finds that orthodox synagogues succeed in attracting often highly educated American women who wish to dedicate their lives to raising children, supporting husbands, and creating strong family units.

\section{Conclusion}

There is much in this paper which is speculative rather than well-established, provocative rather than definitive. One aim has been to show that classical accounts of secularisation tell only a part of the story, for they have in mind chiefly men and the lifeworlds and life-stories of men. The other has been to indicate how much this genderblind perspective fails to see, and how illuminating it may be to consider the lifeworlds of women as well as men. There is no attempt to offer an alternative theory of secularisation - an enterprise which would, in any case, involve taking cognisance of many more factors and theories than can be discussed here. Rather, the attempt has been made to show how the power of some of the most influential existing theories can be enhanced and extended by the simple expedient of taking gender difference more seriously.

\section{NOTER}

1. There is a growing recognition that 'theories' of secularisation have persuasive as well as descriptive force. See, for example, Martin (1969).

2 . Berger has now modified his theory to state not that pluralisation leads to secularisation, but that it leads to a change in the way in which religion is 'held' - i.e. with less objective certainly and more subjective commitment. See Berger (2001).

3 . This argument is developed by Heelas and Woodhead (2005) to explain their recent findings concerning the decline of religion and the growth of spirituality in the UK. They develop it into what they call the 'subjectivisation thesis', which states that those forms of spirituality which resource in- ner subjective life are likely to flourish in contemporary (subjectivised) culture, whilst those forms of religion which fail to perform this function are likely to suffer.

4. See, for example, Abrams 2002, Cancian 1987, Elshtain 1981, Kanter 1977, Wharton 2002.

5 . Churches can be viewed both as primary and intermediate institutions: Public insofar as they are national (or international) with a presence which transcends that of the local congregation; intermediate insofar as they are local, often neighbourhood, institutions. Some churches - like state churches - are more obviously primary, whilst others - like independent congregations - are more obviously intermediate.

6. Clive Field (1987) offers a guide to survey and opinion poll data to 1984 which contains disaggregations by sex.

\section{LITTERATUR}

- Abercrombie, Nicholas, Hill, Stephen, Turner, Brian S. (1986): Sovereign Individuals of Capitalism. Allen and Unwin, London.

- Abrams, Lynn (2002): The Making of Modern Woman. Europe 1789-1918. Longman, London. - Berger, (2001): Postscript. In Linda Woodhead (ed.) Peter Berger and the Study of Religion. Routledge, London, s. 189-198.

- Berger, Peter, Berger, Brigitte and Kellner, Hansfried (1974): The Homeless Mind. Modernization and Consciousness. Penguin, Harmondsworth, UK. - Brannen, Julia and Moss, Peter (1991): Managing Mothers: Dual Earner Households after Maternity Leave. Unwin Hyman, London.

- Brown, Callum (2001): The Death of Christian Britain: Understanding Secularisation 1800-2000. Routledge, London.

- Cancian, Francesca (1987): Love in America: Gender and Self-Development. Cambridge University Press, Cambridge.

- Currie, Robert, Gilbert, Alan and Horsley, Lee (1977): Churches and Churchgoers. Patterns of Church Growth in the British Isles since 1700. Clarendon Press, Oxford.

- Davidman, Lyn (1991): Tradition in a Rootless World: Women turn to Orthodox Judaism. University of California Press, Berkeley.

- Davidoff, Leonore and Hall, Catherine (1987): Family Fortunes: Men and Women of the English Middle Class 1780-1850. Hutchinson, London. - Dobbelaere, Karel (2002): Secularization: An Analysis at Three Levels. Peter Lang, Bruxelles. 
- Douglas, Ann (1978): The Feminization of American Religion. Albert A. Kopf, New York.

- Elshtain, Jean Bethke (1981): Public Man, Private Woman: Women in Social and Political Thought. Robertson, Oxford.

- Ferber, Marianne A. (ed.) (1998): Women in the Labour Market. E. Elgar, Cheltenham, UK, Northampton, MS, USA.

- Field, Clive D. 1987: Non-recurrent Christian Data. In W. F. Maunder (ed.), Religion (Reviews of United Kingdom Statistical Sources), $\mathrm{xx}, \mathrm{Ox}^{-}$ ford, s. 189-504.

- Field, Clive D. (1993): "Adam and Eve: Gender in English Free Church Constituency". Journal of Ecclesiastical History, January, 44 (1) s. 63-79.

. Gill, Robin (1993): The Myth of the Empty

Church. SPCK, London.

- Gill, Robin (2003): The 'Empty' Church Revisited. Ashgate, Aldershot.

- Griffith, R. Marie (1997): God's Daughters. Evangelical Women and the Power of Submission. University of California Press, Berkeley.

- Hartman, Anne (2001): “Anglican Controversies: Debating Private Confession" In: Linda Woodhead (ed.) Reinventing Christianity: Nineteenth-century Contexts. Ashgate, Aldershot.

- Heelas, Paul and Woodhead, Linda (2005): The Spiritual Revolution: Why Religion is Giving Way to Spirituality. Blackwell, Oxford.

- Heiman, Mary (1995): Catholic Devotion in Victorian England. Oxford University Press, Oxford, Clarendon, New York.

- Hochschild, (1989): The Second Shift: Working Parents and the Revolution at Home. University of California Press,Berkeley and London.

- Kanter, Rosabeth Moss (1977): Men and Women of the Corporation. Basic Books, New York.

- Kennelly, Karen (ed.) (1989): American Catholic Women: A Historical Exploration. MacMillan, New York. Collier MacMillan, London.

- Lynd, Robert S. and Lynd, Helen M. (1929): Middletown: A Study in American Culture. Harcourt, Brace and Co, New York.

- Martin, David (1969): The Religious and the Secular: Studies in Secularisation. Routledge and Kegan Paul, London.

- Marx, Karl and Engels, Friedrich (1977): The Communist Manifesto. Reprinted in David McLellan (ed.), Karl Marx. Selected Writings. Oxford University Press, Oxford: s. 221-247.

- Nichols, David (1989): Deity and Domination: Images of God and the State in the Nineteenth and Twentieth Centuries. Routledge, London.

- Putney, Clifford (2001): Muscular Christianity. Manhood and Sports in Protestant America, 1880-
1920. Harvard University Press, Cambridge, MA and London, UK.

- Roper, Lyndal (1989): The Holy Household: Religion, Morals and Order in Reformation Augsburg. Clarendon Press, Oxford.

- Thewlis, Michael, Miller, Linda, Neathey, Fiona and IRS Research (2004): Advancing Women in the Workplace: Statistical Analysis, Working Paper Series No. 12, Women and Equality Unit. Manchester: Equal Opportunities Commission.

- Tyler, May E. (1988): Homeward Bound. New

York, Basic Books.

- Weber, Max (1996): The Protestant Ethic and the Spirit of Capitalism. Routledge, London.

- Wharton, Amy S. (2005): The Sociology of Gender. An Introduction to Theory and Research. Blackwell,Malden, MA and Oxford, UK.

- Woodhead, Linda (2001): "Feminism and the Sociology of Religion: From Gender-Blindness to Gendered Difference." In: Richard K. Fenn (ed.): The Blackwell Companion to the Sociology of Religion. Blackwell, Oxford, UK and Malden, USA, s. 67-84.

- Woodhead, Linda (ed.) (2002): Peter Berger and the Study of Religion. Routledge, London.

- Woodhead, Linda (2004): Introduction to Christianity. Cambridge University Press, Cambridge, UK.

- Woodhead, Linda (2005): Christianity: A Very Short Introduction. Oxford University Press, Oxford.

\section{SUMMARY}

Major theories of secularisation have been gender blind, with the result that men's experience of modernisation has been made central to explanations of religious decline. This paper attempts to show how greater attention to women's distinctive experiences can belp extend the explanatory power of secularisation theory. It begins by introducing two main 'stories' of secularisation, articulated by Weber and Marx, which have shaped much subsequent theory about religious decline. Looking first at industrial society, it shows how the distinctive experiences of modernity, which Weber and Marx discuss, have to do with largely masculine forms of labour. Women's labour, far more confined to the domestic sphe- 
re, would not necessarily have had the same secularising impact - which may belp explain why industrial modernity witnesses only relatively gentle rates of congregational decline. Women's continuing commitment to the churches also helps explain many transformations in the nature of Christian belief and practice in the modern period. Moving into the period of late modernity, from the 1960s, the paper notes a significant increase in the rate of church decline in recent decades, and suggests that this can be explained in terms of changing patterns of women's labour, as differentiation between male and female work begins to diminish. Persistent differences, however, including women's continuing disproportionate responsibility for the work of care, continue to impact upon the nature of male and female religious and spiritual participation in contemporary west-ern societies.

Linda Woodhead, Senior Lecturer in Christian Studies, Lancaster University. 